\title{
Study on the impact of Environmental Factors on Emotional Maturity
}

\author{
Prof. Rajeshwari RR, Dr. S. John Mano Raj \\ Assistant Professor Department of MBA, Dr. Ambedkar Institute of Technology, Bangalore Near Jnana \\ Bharathi Campus Mallath Halli, Bangalore, Karnataka. \\ Associate Professor, Indian Institute of Plantation Management, Bangalore. Near Jnana Bharathi Campus, \\ Mallath Halli, Kengute cIrcle, Bangalore
}

\begin{abstract}
Emotional Maturity comprises social connections, self-confidence and balanced emotions. The study has relevance for all the parents and family members who want to develop the level of emotional maturity among their children. Emotional maturity facilitates in easy social adjustments and makes the children more independent and emotionally stable. Thus the benefits of being more emotional mature arises the need for studying the factors which affect the level of emotional maturity among children. Accordingly the level of emotional maturity can be increased by the parents to a possible extent by changing the different environmental factors which are responsible for the low level of emotional maturity among their children. The study has measured the relationship between emotional maturity and environmental factors and how the impact of environmental factors varies among individuals. . The study is based on the primary data collected through a survey using the emotional maturity scale developed by the researcher as a tool. It has been found from the study that the level of emotional maturity among students differs significantly due to different environmental factors.
\end{abstract}

Keywords: Emotional maturity, family type, family status, environmental factors, management, students, emotional stability, social adjustments and independence.

\section{Introduction}

"The success of an individual exclusively depends on the art of managing emotions which comprises practical skills and the skill to handle people." Goleman (1998)

Emotional Maturity comprises social connections, self-confidence and balanced emotions. Emotional maturity can also be defined as the state in which an adult is supposed to react appropriately and normally at emotional level in the society. In most of the cultures emotional maturity has been considered as ability to control over self and the ability to overwhelm extreme emotional reactions. Emotional maturity means the ability to cope with the unwanted situations, easy adjustments in the society, peer groups, family members, nurturing positive emotions always, increased level of satisfaction towards the responses of the society, selfdependence, ability to delay the needs of instincts, feeling of satisfaction and enjoyment with the available resources. Emotional maturity develops the ability to adjust and make relations with others. Man is a social animal. We live in a society thus we should know the art of making social adjustments while at the same time keeping ourselves happy and satisfied. Emotionally mature people are more compassionate and forgiving in nature and not being critical always. Emotional maturity means the ability to be honest with ourselves. Emotional mature people always involve in doing self-appraisal and making improvements in self. Emotional maturity develops the ability in an individual to accept the reality even if it is too challenging to accept. Emotionally mature person always accept the existing situation and even move towards considering the risks of situations and takes the positive actions according to the risks involved with that situation.

In the modern age of human socialization, everyone face some difficulties in life, youth as well as children due to major changes in the environment settings at home as well as external environment. Family systems have changed, nuclear families have taken the place of joint families, and mothers have also started working in the families which gives birth to day care/creeches concepts in our society, rural population are moving towards urban areas, child birth is under control, people desires only one or two child, thus number of siblings are reducing, population of single parent or divorced parents have increased during last two decades. The difficulties in making social adjustments in the changed environment; is the main reason for many psychosomatic problems which our youth and children are facing such as frustrations, tensions, anxiety and emotional upsets in their day to day life. Therefore, the study of emotional maturity has emerged as a new area to do researches by the researchers. The current study is an attempt to measure the impact of environmental factors over emotional maturity of the management students. 


\section{Review Of Literature}

Kakkar A. (1999) has concluded in his study that the family environment plays a significant role in the emotional maturity of the children during their adulthood stage. At this stage emotional dependence of children on family increases, mainly on mother. (Bharat, 1977) have also found in his study that Indian girls are given less freedom of movement which leads to low level of independence and thus low level of emotional maturity among Indian girls.

Biswas (1992) found that the bond of traditions, affections and religions which creates unity among family members is weakening now days. Rising trend of nuclear families has depleted the emotional setting of the family members. Therefore, Indian youngsters are gradually becoming more self-directed and independent in nature.

Mishra (1994) has conducted a study to know the impact of living environment of students on their emotional maturity level. It was found from the study that the emotional maturity level of hostlers were higher than the non-hostellers students. Thus the living environment has a positive relationship with the emotional maturity.

Gakhar, S. C. (2003) also found that the emotional maturity of hostellers and non-hostlers are significantly different which is due to environmental setting at home and at hostels.

Chaudhary and Bajaj, (1993) have made a comparative study of emotional maturity among teenagers who lives at home and at orphanage. Level of emotional maturity has been found higher in those who are living at home with their parents than those who are living at orphanages.

Larsen and Juhasz (1985) stated that positive attitude of parents towards child-care is positively related to emotional maturity and child development.

Kaur, S. (2000) have conducted a study to measure the relationship between emotional maturity and home environment. Positive and significant relationship has been found between emotional maturity and the home environment. The area of residence has also been related to the emotional maturity of the students.

David J. Landry and Jacqueline E, Darroch (2002) in his research concluded from the study that emotional maturity varies due to different environmental settings. Landry and Darroch (2002) found that emotional maturity of a child gets affected due to various environmental factors. Darwin Nelson (2005) conducted a study to measure the relationship emotional Intelligence and emotional maturity. It was found from the study that the parents who focus on the early childhood education of the children tends to be more emotionally mature. Judith (2008) stated in his study that different type of family systems has impact over the emotional maturity of the youngsters. Family system also affects the level of emotional independence and social adjustments among the youngsters. Nanda P., Chawla A. (2010) has measured the impact of family type on emotional maturity of the young girls who belongs to urban area. It was found from the study that family type and locality of residence has a direct and positive impact over the emotional maturity of the young girls. Shah and Sharma (1984) stated in their studies that friendly environment at home helps in higher level of intelligence of students and therefore higher level of emotional maturity among students. Albers et al. (1986) reported in his research that nuclear family leads to low level of emotional maturity.

Lau and Kwok (2000) found in his study that organized, arranged and friendly environment at home leads to the positive development among children and higher level of emotional maturity. Williamson (2006) observed in his study that emotional maturity and self-confidence among college going students is highly influenced by the family settings and home environment. (Alberset al. 1986) have stated in his research that poor quality of home environment leads to the lower level of emotional maturity. Similarly, Forehand and Thomas, (1992) and Sun (2001) have found that broken homes or in case of divorced parents the emotional maturity of the children remains low.

Tyagi (1985) has also found in the study that emotional maturity is positively correlated to personal and social adjustment. Dean and Bruton B. T. (1989) have examined the impact of social background factors over emotional maturity. The study has concluded an inverse relationship between social background factors and emotional maturity.

Rosa. M.C., Preethi.C (2012) has conducted a study to measure the relationship between Academic stress and Emotional maturity of working and Non-working mothers. It was found from the study that the emotional maturity is higher in children whose mothers' are working. Emotional maturity of children of non-working mothers is lower. Suneetha \& Vijayalaxmi (2007) measured the impact of mother working status on the emotional maturity of adolescents. The researchers have made a comparative study of students of working mothers' and house makers. It was found from the study that children of employed mothers are more emotional maturity than the children whose mothers' are house-makers. Jackson A.P. (2003) has concluded that living environment which includes the family and neighborhood environment have a significant relationship with the emotional maturity of the children. Environment plays a big role in development of behaviors and intellectual among children. 
Sarabjit Kaur (2000) in her thesis 'Effect of intelligence and her emotional maturity on academic achievement of graduate level students concluded that there is somewhat significant differences exist among science and arts students with respect to intelligence and emotional maturity.

From the literature review it is clear that environment has a significant bearing over emotional maturity. Researchers have used few variables related to the environment based on review of literature to check the impact of environmental factors over emotional maturity. Most of the studies have focused only school going children and degree students for studying the emotional maturity. This study will bridge the gap of literature. Six variables which defines the environment has been used in the study altogether. The study also aims to measure the emotional maturity among management students who are pursuing master degree in business administration in different colleges.

\section{Objectives}

The following are the main objectives of the study:

- To measure the emotional maturity among post graduate students of management studies.

- To measure the impact of environmental factors over emotional maturity.

\section{Research Methodology}

The study has been conducted on the management (MBA) students studying indifferent colleges affiliated to Visvesvaraya Technological University, Belgaum in the Karnataka State. Secondary data has been used to study the review of literature and to identify the gap in the literature \& giving direction for the study. Self-developed questionnaire for measuring the emotional maturity among management students has been used in the study. Emotional Maturity scale consists total 32items; all items were related to the emotional maturity. Responses of the respondents have been recorded using Likert's five point scale ranging from 1 to 5,1 for strongly disagree and 5 for strongly agree.

Table 1: Table showing the scoring of emotional maturity scale

\begin{tabular}{|l|l|l|l|l|}
\hline 32 items $-32 * 5=160$ \\
\hline $\begin{array}{l}\text { Very High } \\
\text { EM }\end{array}$ & High EM & $\begin{array}{c}\text { Average/ Medium } \\
\text { EM }\end{array}$ & Low EM & $\begin{array}{c}\text { Very low } \\
\text { EM }\end{array}$ \\
\hline $129-160$ & $97-128$ & $65-96$ & $33-64$ & $1-32$ \\
\hline $\begin{array}{l}\text { Maximum score }=160 \\
\text { Minimum score }=1 \\
\text { Interval is 32. }\end{array}$ \\
\hline
\end{tabular}

The biographical data of the students has been used as variables for environmental factors of the students which includes the variables like; family type,family status, number of parents, working status of mother, number of siblings, locality of residence. Total 150 respondents were covered in the study. Out of 150 , only 110 were duly filled up by the respondents were used for further analysis. Thus the rejection rate was 26.7 percent in the study. The reliability of the questionnaire has been measured through Cronbach alpha which was 0.923, which is an acceptable value and thus the questionnaire was used for further analysis.

\section{Data Analysis}

Emotional maturity of the management students has been measured as a mean value of all the 32 items used in the emotional maturity scale. On the basis of the mean value of the emotional maturity, the variable emotional maturity has been categorized under five categories, as 1 for very low level of emotional maturity, 2 for low level of emotional maturity, 3 for average level of emotional maturity, 4 as high level of emotional maturity and 5 as very high level of emotional maturity. The following graph shows the percentage of students under five categories of the emotional maturity.

Table 2: Table showing the number of students falling in each category of emotional maturity scale.

\begin{tabular}{|c|c|c|c|c|}
\hline \multicolumn{5}{|c|}{32 items $-32 * 5=160$} \\
\hline $\begin{array}{l}\text { Very High } \\
\text { EM }\end{array}$ & High EM & $\begin{array}{r}\text { Average } \\
\text { EM }\end{array}$ & Low EM & $\begin{array}{l}\text { Very low } \\
\text { EM }\end{array}$ \\
\hline $\begin{array}{l}129-160 \\
\text { (31 students) }\end{array}$ & $\begin{array}{l}97-128 \\
\text { (40 students) }\end{array}$ & $\begin{array}{l}65-96 \\
\text { (17 students) }\end{array}$ & $\begin{array}{l}33-64 \\
\text { (14 students) }\end{array}$ & $\begin{array}{l}1-32 \\
\text { (8 students) }\end{array}$ \\
\hline
\end{tabular}




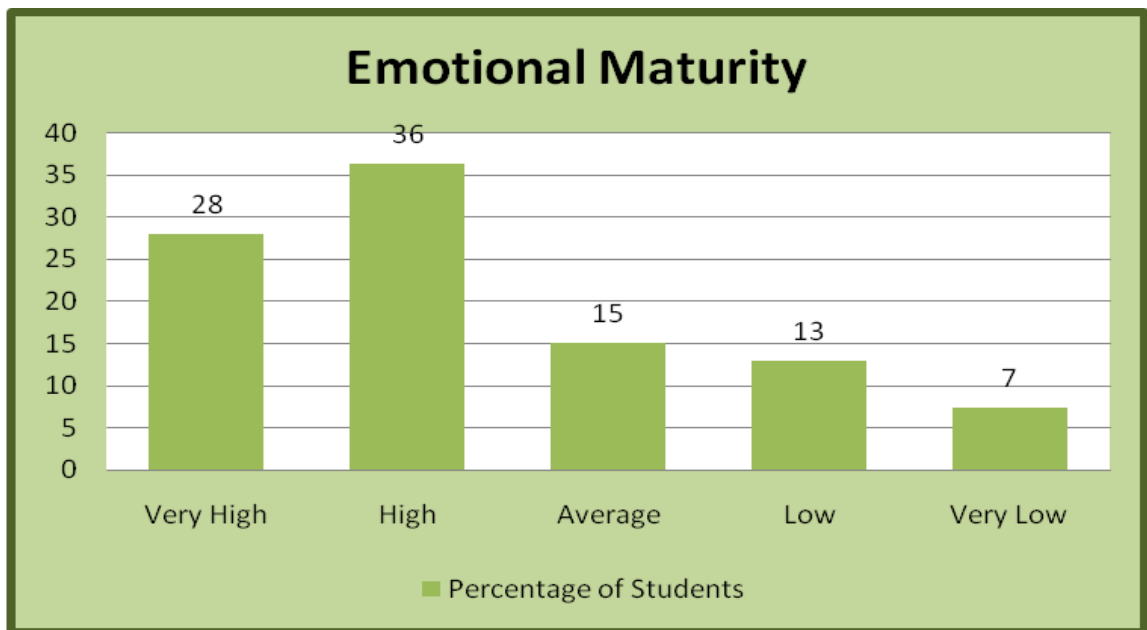

Fig1: Percentage of students with different level of Emotional Maturity

Interpretation: The graph 1 shows that 36 percent $(40 / 110 * 100=36.3 \% .1 \%)$ of the total respondents have been found highly emotionally mature followed by students with very high level of emotional maturity i.e. 28 percent $(31 / 110 * 100=28.1 \%)$ of the total respondents. Total 20 percent $[(13+7) / 110 * 100=18.1 \%]$ of total respondents have been found with low and very low level of emotional maturity. Thus overall it can be interpreted that management students from the different colleges of Karnataka state, have been found emotionally mature.

In order to measure the impact of different environmental factors over the emotional maturity, cross tabulation of environmental factors and emotional maturity has been performed along with Chi Square test. The following section explains the cross tabulation and chi square in detail. Null Hypothesis $1\left(\mathrm{H}_{01}\right)$ : There is no relationship between family type and emotional maturity.

Table 3: Cross tabulation of Family type and Emotional Maturity

\begin{tabular}{|c|c|c|c|c|c|c|c|}
\hline \multicolumn{2}{|c|}{ Family Type } & \multirow{2}{*}{$\begin{array}{l}\text { Very High } \\
19\end{array}$} & \multirow{2}{*}{$\begin{array}{l}\text { High } \\
31\end{array}$} & \multirow{2}{*}{$\begin{array}{l}\text { Average } \\
10\end{array}$} & \multirow{2}{*}{$\begin{array}{l}\text { Low } \\
10\end{array}$} & \multirow{2}{*}{$\begin{array}{l}\text { Very } \\
\text { Low } \\
6\end{array}$} & \multirow{2}{*}{$\begin{array}{l}\text { Total } \\
76 \\
\end{array}$} \\
\hline Joint & Count & & & & & & \\
\hline Family & $\begin{array}{l}\% \text { within Family } \\
\text { Type }\end{array}$ & $25.00 \%$ & $40.79 \%$ & $13.16 \%$ & $13.16 \%$ & $7.89 \%$ & $100 \%$ \\
\hline \multirow{2}{*}{$\begin{array}{l}\text { Nuclear } \\
\text { Family }\end{array}$} & Count & 12 & 9 & 6 & 4 & 3 & 34 \\
\hline & $\begin{array}{l}\text { \% within Family } \\
\text { Type }\end{array}$ & $35.29 \%$ & $26.47 \%$ & $17.65 \%$ & $11.76 \%$ & $8.82 \%$ & $100 \%$ \\
\hline \multirow[t]{2}{*}{ Total } & Count & 31 & 40 & 17 & 14 & 8 & 110 \\
\hline & $\begin{array}{l}\% \text { within Family } \\
\text { Type }\end{array}$ & $28.18 \%$ & $36.36 \%$ & $15.45 \%$ & $12.73 \%$ & $7.27 \%$ & $100 \%$ \\
\hline
\end{tabular}

Interpretation: It can be interpreted from the cross tabulation of family type and emotional maturity that majority of the very high and high emotionally mature students are those who belongs to Joint family. It can also be seen that the management students who are living in nuclear families are not highly emotionally mature. The tabulated value of chi square is 13.277 at 1 percent level of significance with $\mathrm{df} 4$. The calculated value of chi square at df 4 is 41.532 , which is greater than the tabulated value thus the null hypothesis 1 stands to be rejected. Therefore, it can be said that family type has a significant relationship with the emotional maturity. The emotional maturity of management students differs as per the family type they belong to.

Null Hypothesis $2\left(\mathrm{H}_{02}\right)$ : There is no relationship between family status and emotional maturity.

Table 4: Cross tabulation of Family status and Emotional Maturity

\begin{tabular}{|l|l|l|l|l|l|l|l|}
\hline Family Status & Very High & High & Average & Low & Very low & Total \\
\hline \multirow{2}{*}{$\begin{array}{l}\text { Upper Level } \\
(>\mathbf{1 0 L})\end{array}$} & Count & 14 & 16 & 4 & 2 & 1 & 37 \\
\cline { 2 - 9 } & $\begin{array}{l}\% \text { within Family } \\
\text { Status }\end{array}$ & $37.84 \%$ & $43.24 \%$ & $10.81 \%$ & $5.41 \%$ & $2.70 \%$ & $100 \%$ \\
\hline $\begin{array}{l}\text { Upper } \\
\text { Middle } \\
(\mathbf{6} \text { to 10L) }\end{array}$ & $\begin{array}{l}\text { Count within Family } \\
\text { Status }\end{array}$ & $26.67 \%$ & $36.67 \%$ & $16.67 \%$ & $13.33 \%$ & $6.67 \%$ & $100 \%$ \\
\hline $\begin{array}{l}\text { Middle } \\
(\mathbf{1} \text { to 5 L) }\end{array}$ & $\begin{array}{l}\text { Count within Family } \\
\text { Status }\end{array}$ & 6 & 10 & 4 & 3 & 3 & 26 \\
\hline
\end{tabular}


Study on the impact of Environmental Factors on Emotional Maturity

\begin{tabular}{|c|c|c|c|c|c|c|c|}
\hline \multirow[b]{2}{*}{$\begin{array}{l}\text { Lower } \\
(<1 \text { lakh })\end{array}$} & Count & 2 & 3 & 3 & 6 & 3 & 17 \\
\hline & $\begin{array}{ll}\% \text { within } & \text { Family } \\
\text { Status } & \end{array}$ & $11.76 \%$ & $17.65 \%$ & $17.65 \%$ & $35.29 \%$ & $17.65 \%$ & $100 \%$ \\
\hline \multirow[b]{2}{*}{ Total } & Count & 31 & 40 & 17 & 14 & 8 & 110 \\
\hline & $\begin{array}{ll}\% \text { within } & \text { Family } \\
\text { Status } & \end{array}$ & $28.18 \%$ & $36.36 \%$ & $15.45 \%$ & $12.73 \%$ & $7.27 \%$ & $100 \%$ \\
\hline
\end{tabular}

Interpretation: It can be interpreted from the cross tabulation of family status and emotional maturity that majority of the very high and high emotionally mature students are those whose family status is upper level, followed by upper middle level and middle level. It can also be seen that the management students whose family status is lower level are having low and very low level of emotional maturity. The calculated value of chi square is 74.764 at $12 \mathrm{df}$, which is greater than the tabulated value of chi square $=26.217$ at $4 \mathrm{df}$ which leads to be rejection of the null hypothesis 2 . Therefore it can be interpreted that there is a significant relationship between family status and the emotional maturity.

Null Hypothesis $3\left(\mathrm{H}_{03}\right)$ : There is no relationship between number of parents and emotional maturity.

Table 5: Cross tabulation of Number of Parents and Emotional Maturity

\begin{tabular}{|c|c|c|c|c|c|c|c|}
\hline \multicolumn{2}{|c|}{ Number of Parent } & Very High & High & Average & Low & Very low & Total \\
\hline \multirow{2}{*}{$\begin{array}{l}\text { Single } \\
\text { Parent }\end{array}$} & Count & 10 & 13 & 4 & 4 & 3 & 34 \\
\hline & $\begin{array}{l}\% \text { within Number of } \\
\text { Parent }\end{array}$ & $28.42 \%$ & $38.95 \%$ & $12.63 \%$ & $12.63 \%$ & $7.37 \%$ & $100 \%$ \\
\hline \multirow{3}{*}{$\begin{array}{l}\text { Both } \\
\text { Parents }\end{array}$} & Count & 17 & 22 & 9 & 3 & 2 & 53 \\
\hline & $\%$ within & \multirow[t]{2}{*}{$32.08 \%$} & \multirow[t]{2}{*}{$41.51 \%$} & \multirow[t]{2}{*}{$16.98 \%$} & \multirow[t]{2}{*}{$5.66 \%$} & \multirow[t]{2}{*}{$3.77 \%$} & \multirow[t]{2}{*}{$100 \%$} \\
\hline & Number of Parent & & & & & & \\
\hline \multirow[t]{3}{*}{ None } & Count & 4 & 5 & 3 & 7 & 4 & 23 \\
\hline & $\%$ within & \multirow[t]{2}{*}{$17.39 \%$} & \multirow[t]{2}{*}{$21.74 \%$} & \multirow[t]{2}{*}{$13.04 \%$} & \multirow[t]{2}{*}{$30.43 \%$} & \multirow[t]{2}{*}{$17.39 \%$} & \multirow[t]{2}{*}{$100 \%$} \\
\hline & Number of Parent & & & & & & \\
\hline \multirow[t]{3}{*}{ Total } & Count & 31 & 40 & 17 & 14 & 8 & 110 \\
\hline & $\%$ within & \multirow[t]{2}{*}{$28.18 \%$} & \multirow[t]{2}{*}{$36.36 \%$} & \multirow[t]{2}{*}{$15.45 \%$} & \multirow[t]{2}{*}{$12.73 \%$} & \multirow[t]{2}{*}{$7.27 \%$} & \multirow[t]{2}{*}{$100.00 \%$} \\
\hline & Number of Parent & & & & & & \\
\hline
\end{tabular}

Interpretation: Table 5 shows the cross tabulation of number of parents and emotional maturity. It can be seen from the table 5 that the management students who are blessed with both the parents mother and father are having high and very high level of emotionally maturity while the management students whose both the parents are not with them are less emotionally mature. The moderate level of emotionally maturity has been recorded for the students who have single parent either mother or father. The chi square test has been conducted to test the null hypothesis 3 which states that there is no relationship between number of parents and emotional maturity. The value of chi square is 17.362 at $4 \mathrm{df}$, has been found to be significant at 5 percent level of significance, therefore the null hypothesis 3 has been rejected. Thus it can be interpreted that emotional maturity and number of parents has a significant relationship with each other.

Null Hypothesis $4\left(\mathrm{H}_{04}\right)$ : There is no relationship between working status of mother and emotional maturity.

Table 6: Cross tabulation of Working Status of Mother and Emotional Maturity

\begin{tabular}{|l|l|l|l|l|l|l|l|}
\hline Working Status of Mother & Very High & High & Average & Low & Very low & Total \\
\hline \multirow{3}{*}{ Working } & Count & 24 & 30 & 10 & 4 & 2 & 70 \\
\cline { 2 - 8 } & $\begin{array}{l}\% \text { within Working } \\
\text { Status of Mother }\end{array}$ & $34.29 \%$ & $42.86 \%$ & $14.29 \%$ & $5.71 \%$ & $2.86 \%$ & $100 \%$ \\
\hline $\begin{array}{l}\text { Non- } \\
\text { Working }\end{array}$ & 7 & 10 & 7 & 10 & 6 & 40 \\
\cline { 2 - 8 } & $\begin{array}{l}\text { Count within Working Status } \\
\text { of Mother }\end{array}$ & $17.50 \%$ & $25.00 \%$ & $17.50 \%$ & $25.00 \%$ & $15.00 \%$ & $100 \%$ \\
\hline \multirow{2}{*}{ Total } & Count & 31 & 40 & 17 & 14 & 8 & 110 \\
\cline { 2 - 7 } & $\begin{array}{l}\% \text { within Working Status } \\
\text { of Mother }\end{array}$ & $28.18 \%$ & $36.36 \%$ & $15.45 \%$ & $12.73 \%$ & $7.27 \%$ & $100 \%$ \\
\hline Chi Square Value =21.189, Df =4, Significant at 1 percent level of significance & & & \\
\hline
\end{tabular}

Interpretation: Table 6 explains the cross tabulation of the working status of mother and emotional maturity of management students. High and very high level of emotional maturity has been recorded for those students whose mothers are working not house wives. The students whose mothers are housewives have low level of emotional maturity. Null hypothesis 4 has been tested through chi square test which states that there is no relationship between working status of mother and the emotional maturity. The calculated value of chi square has been found greater than the tabulated value of chi square at $4 \mathrm{df}$ with 1 percent level of significance, which 
leads to the rejection of null hypothesis 4 . Thus it can be said that working status of students' mother and the emotional maturity of the students' are significantly related with each other.

Null Hypothesis $5\left(\mathrm{H}_{05}\right)$ : There is no relationship between $\mathrm{n}$ umber of siblings and emotional maturity.

Table 7: Cross tabulation of Number of siblings and Emotional Maturity

\begin{tabular}{|c|c|c|c|c|c|c|c|}
\hline \multicolumn{2}{|c|}{ Number of Siblings } & Very High & High & Average & Low & Very low & Total \\
\hline \multirow[t]{3}{*}{1 to 2} & Count & 9 & 11 & 5 & 2 & 1 & 28 \\
\hline & $\%$ within & \multirow[t]{2}{*}{$32.14 \%$} & \multirow[t]{2}{*}{$39.29 \%$} & \multirow[t]{2}{*}{$17.86 \%$} & \multirow[t]{2}{*}{$7.14 \%$} & \multirow[t]{2}{*}{$3.57 \%$} & \multirow[t]{2}{*}{$100 \%$} \\
\hline & Number of Siblings & & & & & & \\
\hline \multirow[t]{3}{*}{2 to 3} & Count & 5 & 7 & 3 & 4 & 2 & 21 \\
\hline & $\%$ within & \multirow[t]{2}{*}{$23.81 \%$} & \multirow[t]{2}{*}{$33.33 \%$} & \multirow[t]{2}{*}{$14.29 \%$} & \multirow[t]{2}{*}{$19.05 \%$} & \multirow[t]{2}{*}{$9.52 \%$} & \multirow[t]{2}{*}{$100 \%$} \\
\hline & Number of Siblings & & & & & & \\
\hline \multirow[t]{3}{*}{ More than 3} & Count & 3 & 2 & 2 & 6 & 4 & 17 \\
\hline & $\%$ within & \multirow[t]{2}{*}{$17.65 \%$} & \multirow[t]{2}{*}{$11.76 \%$} & \multirow[t]{2}{*}{$11.76 \%$} & \multirow[t]{2}{*}{$35.29 \%$} & \multirow[t]{2}{*}{$23.53 \%$} & \multirow[t]{2}{*}{$100.00 \%$} \\
\hline & Number of Siblings & & & & & & \\
\hline \multirow[t]{3}{*}{ None } & Count & 14 & 20 & 6 & 2 & 2 & 44 \\
\hline & $\%$ within & \multirow[t]{2}{*}{$31.82 \%$} & \multirow[t]{2}{*}{$45.45 \%$} & \multirow[t]{2}{*}{$13.64 \%$} & \multirow[t]{2}{*}{$4.55 \%$} & \multirow[t]{2}{*}{$4.55 \%$} & \multirow[t]{2}{*}{$100.00 \%$} \\
\hline & Number of Siblings & & & & & & \\
\hline \multirow[t]{3}{*}{ Total } & Count & 31 & 40 & 17 & 14 & 8 & 110 \\
\hline & $\%$ within & \multirow[t]{2}{*}{$28.18 \%$} & \multirow[t]{2}{*}{$36.36 \%$} & \multirow[t]{2}{*}{$15.45 \%$} & \multirow[t]{2}{*}{$12.73 \%$} & \multirow[t]{2}{*}{$7.27 \%$} & \multirow[t]{2}{*}{$100.00 \%$} \\
\hline & Number of Siblings & & & & & & \\
\hline
\end{tabular}

Interpretation: Cross tabulation of the number of siblings and emotional maturity among management students has been shown in the table 7. It can be seen from the table 7 that students who do not have any siblings neither brother nor sister are found to be highly emotionally mature followed by the students who have one or two siblings. The students who have more than 3 siblings are found to have low level of emotional maturity. The chi square test has been conducted to check whether there is any relationship exists between number of siblings and emotional maturity of the students. The chi square value is found to be 23.054 at $12 \mathrm{df}$ which is significant at 5 percent level of significance. Thus it can be interpreted that number of siblings and emotional maturity are significantly related to each other.

Null Hypothesis $6\left(\mathrm{H}_{06}\right)$ : There is no relationship between area of residence and emotional maturity.

Table 8: Cross tabulation of Area of Residence and Emotional Maturity

\begin{tabular}{|c|c|c|c|c|c|c|c|}
\hline \multicolumn{2}{|c|}{ Area of Residence } & Very High & High & Average & Low & Very low & Total \\
\hline \multirow[t]{3}{*}{ Urban } & Count & 15 & 25 & 7 & 2 & 1 & 50 \\
\hline & $\%$ within & \multirow[t]{2}{*}{$30.00 \%$} & \multirow[t]{2}{*}{$50.00 \%$} & \multirow[t]{2}{*}{$14.00 \%$} & \multirow[t]{2}{*}{$4.00 \%$} & \multirow[t]{2}{*}{$2.00 \%$} & \multirow[t]{2}{*}{$100 \%$} \\
\hline & Area of Residence & & & & & & \\
\hline \multirow[t]{3}{*}{ Rural } & Count & 4 & 13 & 3 & 8 & 5 & 33 \\
\hline & $\%$ within & \multirow[t]{2}{*}{$12.12 \%$} & \multirow[t]{2}{*}{$39.39 \%$} & \multirow[t]{2}{*}{$9.09 \%$} & \multirow[t]{2}{*}{$24.24 \%$} & \multirow[t]{2}{*}{$15.15 \%$} & \multirow[t]{2}{*}{$100 \%$} \\
\hline & Area of Residence & & & & & & \\
\hline \multirow{3}{*}{$\begin{array}{l}\text { Semi- } \\
\text { Rural }\end{array}$} & Count & 10 & 5 & 6 & 4 & 2 & 27 \\
\hline & $\%$ within & \multirow[t]{2}{*}{$37.04 \%$} & \multirow[t]{2}{*}{$18.52 \%$} & \multirow[t]{2}{*}{$22.22 \%$} & \multirow[t]{2}{*}{$14.81 \%$} & \multirow[t]{2}{*}{$7.41 \%$} & \multirow[t]{2}{*}{$100 \%$} \\
\hline & Area of Residence & & & & & & \\
\hline \multirow[t]{3}{*}{ Total } & Count & 31 & 40 & 17 & 14 & 8 & 110 \\
\hline & $\%$ within & \multirow[t]{2}{*}{$28.18 \%$} & \multirow[t]{2}{*}{$36.36 \%$} & \multirow[t]{2}{*}{$15.45 \%$} & \multirow[t]{2}{*}{$12.73 \%$} & \multirow[t]{2}{*}{$7.27 \%$} & \multirow[t]{2}{*}{$100 \%$} \\
\hline & Area of Residence & & & & & & \\
\hline
\end{tabular}

Interpretation: Table 8 shows the cross tabulation of area of residence of the students and the level of their emotional maturity. The students who live in urban area are having high level of emotional maturity followed by the students from semi-urban area. The students from rural area are those who have low level of emotional maturity. Null hypothesis 6 states that there is no relationship between area of residence and the emotional maturity of management students. Chi square test has been conducted to test the null hypothesis 6 . It was found from the chi square test that area of residence and emotional maturity are significantly related to each other, thus null hypothesis 6 stands to be rejected. 
Table 9: Showing the summary of the analysis.

\begin{tabular}{|c|c|c|c|}
\hline Sl. No & Hypothesis & Independent Variables & Significance \\
\hline 1. & $\begin{array}{l}\text { Null Hypothesis } 1\left(\mathrm{H}_{01}\right) \text { : } \\
\text { There is no relationship } \\
\text { between family type and } \\
\text { emotional maturity. }\end{array}$ & $\begin{array}{l}\text { Family type } \\
\text { - Joint Family } \\
\text { - Nuclear } \\
\text { Family }\end{array}$ & $\begin{array}{l}\text { Very high and high emotionally mature students are those who belongs to } \\
\text { Joint family. It can also be seen that the management students who are } \\
\text { living in nuclear families are not highly emotionally mature. Therefore, it } \\
\text { can be said that family type has a significant relationship with the emotional } \\
\text { maturity. }\end{array}$ \\
\hline 2. & $\begin{array}{l}\text { Null Hypothesis } 2\left(\mathrm{H}_{02}\right) \\
\text { There is no relationship } \\
\text { between family status and } \\
\text { emotional maturity }\end{array}$ & $\begin{array}{l}\text { Family Status } \\
\text { - Upper Level } \\
\text { - Upper Middle } \\
\text { Level } \\
\text { - Middle Level } \\
\text { - Lower Level }\end{array}$ & $\begin{array}{l}\text { Majority of students whose family status is upper level, upper middle level } \\
\text { and middle level are highly emotionally matured. It can also be seen that the } \\
\text { management students whose family status is lower level are having low } \\
\text { emotional maturity. Therefore it can be interpreted that there is a significant } \\
\text { relationship between family status and the emotional maturity. }\end{array}$ \\
\hline 3. & $\begin{array}{l}\text { Null Hypothesis } 3\left(\mathrm{H}_{03}\right) \text { : } \\
\text { There is no relationship } \\
\text { between number of parents } \\
\text { and emotional maturity }\end{array}$ & $\begin{array}{l}\text { No. of Parents } \\
\text { - Single Parent } \\
\text { - Both Parents } \\
\text { - None }\end{array}$ & $\begin{array}{l}\text { The students who are blessed with both the parents mother and father are } \\
\text { having high and very high level of emotionally maturity while the } \\
\text { management students whose both the parents are not with them are less } \\
\text { emotionally mature. The moderate level of emotionally maturity has been } \\
\text { recorded for the students who have single parent either mother or father. } \\
\text { Thus it can be interpreted that emotional maturity and number of parents has } \\
\text { a significant relationship with each other. }\end{array}$ \\
\hline 4. & $\begin{array}{l}\text { Null Hypothesis } 4\left(\mathrm{H}_{04}\right) \text { : } \\
\text { There is no relationship } \\
\text { between working status of } \\
\text { mother and emotional } \\
\text { maturity. }\end{array}$ & $\begin{array}{l}\text { Working Status of the } \\
\text { Mother } \\
\text { - Working } \\
\text { - Nonworking }\end{array}$ & $\begin{array}{l}\text { High and very high level of emotional maturity has been recorded for those } \\
\text { students whose mothers are working. The students whose mothers are } \\
\text { housewives have low level of emotional maturity. Thus it can be said that } \\
\text { working status of students' mother and the emotional maturity of the } \\
\text { students' are significantly related with each other. }\end{array}$ \\
\hline 5. & $\begin{array}{l}\text { Null Hypothesis } 5\left(\mathrm{H}_{05}\right) \text { : } \\
\text { There is no relationship } \\
\text { between number of } \\
\text { siblings and emotional } \\
\text { maturity. }\end{array}$ & $\begin{array}{l}\text { No. of Siblings } \\
\text { - None } \\
-1 \text { to } 2 \\
-2 \text { to } 3 \\
\text { - More than } 3 \\
\end{array}$ & $\begin{array}{l}\text { Students who do not have any siblings neither brother nor sister are found to } \\
\text { be highly emotionally mature followed by the students who have one or two } \\
\text { siblings. The students who have more than } 3 \text { siblings are found to have low } \\
\text { level of emotional maturity. Thus it can be interpreted that number of } \\
\text { siblings and emotional maturity are significantly related to each other. }\end{array}$ \\
\hline 6. & $\begin{array}{l}\text { Null Hypothesis } 6\left(\mathrm{H}_{06}\right) \\
\text { There is no relationship } \\
\text { between area of residence } \\
\text { and emotional maturity. }\end{array}$ & $\begin{array}{l}\text { Area of Residence } \\
\text { - Urban } \\
\text { - Rural } \\
\text { - Semi Urban }\end{array}$ & $\begin{array}{l}\text { The students who live in urban area are having high level of emotional } \\
\text { maturity followed by the students from semi-urban area. The students from } \\
\text { rural area are those who have low level of emotional maturity. It was found } \\
\text { that area of residence and emotional maturity are significantly related to } \\
\text { each other. }\end{array}$ \\
\hline
\end{tabular}

Mean value of emotional maturity for all the proxy variables which are used as environmental factors has been given in self-explanatory table 10 in detail. The variables with highest mean values of emotional maturity have been highlighted in the table 10 .

Table 10: Mean value of emotional maturity on the basis of various environmental factors

\begin{tabular}{|c|c|c|c|}
\hline Family Type & $\begin{array}{l}\text { Mean value of Emotional } \\
\text { Maturity }\end{array}$ & Working Status of Mother & $\begin{array}{l}\text { Mean value of Emotional } \\
\text { Maturity }\end{array}$ \\
\hline Joint Family & 4.37 & Working & 4.82 \\
\hline Nuclear Family & 3.11 & Non-Working & 3.13 \\
\hline Family Status & $\begin{array}{l}\text { Mean value of Emotional } \\
\text { Maturity }\end{array}$ & Number of Siblings & $\begin{array}{l}\text { Mean value of Emotional } \\
\text { Maturity }\end{array}$ \\
\hline Upper & 4.67 & 1 to 2 & 3.97 \\
\hline Upper Middle & 4.17 & 2 to 3 & 3.36 \\
\hline Middle & 3.21 & More than 3 & 2.15 \\
\hline Lower & 2.76 & None & 4.1 \\
\hline Number of Parents & $\begin{array}{l}\text { Mean value of Emotional } \\
\text { Maturity }\end{array}$ & Area of Residence & $\begin{array}{l}\text { Mean value of Emotional } \\
\text { Maturity }\end{array}$ \\
\hline Single Parent & 3.51 & Urban & 4.23 \\
\hline Both Parents & 4.87 & Rural & 3.17 \\
\hline None & 2.54 & Semi-Urban & 2.87 \\
\hline
\end{tabular}




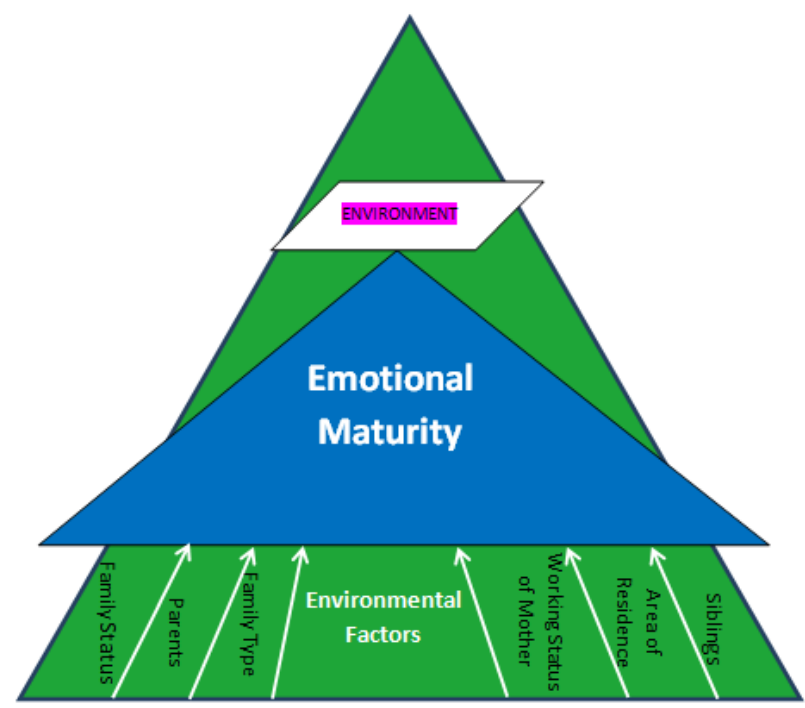

Figure 2: Model showing direct impact of environmental factors on emotional maturity

Figure 2 show the model which has been developed from the current study. This model shows that environmental factors have a direct impact over the emotional maturity of the management students. The students who belong to joint family, have no siblings, lives in urban area with their father and working mother both and from upper level of family status are having high level of emotional maturity. The students who belong to nuclear family, have more than three siblings, lives in rural area without their parents or single parent and from lower level of family status are having low level of emotional maturity. The students who live in joint family and with their parents receive ethical values, cultural values from their family members and from their parents. They also gets the strength and full support from their family members thus enables the students to feel more self-confident and helps in easily social adjustments and also helps in coping with stressful situations. Therefore the students who live joint family and with their parents are found to be more emotional mature than those who live in nuclear family and without their parents. The feature of independence develops in the students who are single child of their parent and whose mother is working somewhere. Thus enables those to become more emotional mature. A student who lives in urban area and from high status family never lacks any facilities or necessary things they need to live their life in a comfortable way. Thus enables the students to become more emotionally mature than those who live in rural area and have lower family status.

\section{Conclusion}

It can be concluded from the study that environment has a great impact over the emotional maturity. Students having both parents, single parent or without parent, living in joint family or nuclear family, single child of their parents or having few siblings, enjoying a high status or lower status of family, residing in urban or rural area; all these factors effects their level of emotional maturity. Positive environmental factors may lead to high level of emotional maturity among students while negative settings of environment may lead to low level of emotional maturity among students. The study is relevant for all the guardians who want their children to be emotionally mature. The study has shown that emotional maturity can be increased by making changes in the current environmental settings which their children are facing currently. The study has some limitations also. The study is limited only to the few colleges of Karnataka state, which can be extended further. The study is also limited only to management students, the study can be performed on the students of other streams as well such as, Arts, Science and Engineering students. The further scope of the study is to make a comparative study of emotional maturity among the students from different streams.

\section{References}

[1]. Albers, Lawrence J., Doane, Jeri A. and Mintz, Jim (1986). Social Competence and Family Environment: 15-Year Follow-Up of Disturbed Adolescents. Family Process, Vol. 25 (3), pp. 379-389.

[2]. Bharat, S. (1977). Family socialization of the Indian Child. Trends in Social Science Research, 4, $201-216$.

[3]. Biswas, P. C. (1992). Perception of parental behaviour and adolescent's frustration. Indian Journal of Social Work, 4, 669-678.

[4]. Chaudhary, N. \& Bajaj, N. (1993). Emotional maturity as a correlate of the mental health of adolescents staying at home and orphanages. Journal of Indian Retrieved http://shodhganga.inflibnet.ac.in/bitstream/10603/7062/12/12_bibliography.pdf.

[5]. David J. Landry, Jacqueline E. Darroch, Susheela Singh and Jenny Higgins (2002). Factors Associated with the Content of Sex Education in U.S. Public Secondary Schools. Retrieved from https://www.guttmacher.org/pubs/journals/3526103.html on 25th May 2015.

[6]. Dean, D.G., Bruton, B.T. (1989). Alienation and Emotional Maturity, Research Journal, Vol.22, pp. 221-230.

DOI: $10.9790 / 487 X-1905040109 \quad$ www.iosrjournals.org $\quad 8 \mid$ Page


[7]. Forehand, R., Mulhern, T., \& Gordon, D. (1970). Psychological services in the institution. In A. A. Baumeister and E. C. Butterfield (Eds.), Residential Facilities for the Mentally Retarded. Chicago: Aldine, pp. 373-396.

[8]. Geeta S., Vijaylaxmi A. (2006). Impact of emotional maturity on stress and self-confidence of adolescents, Journal of Indian academy of Applied Psychology, 2006, Vol.32, No. 1, pp. 66-70.

[9]. Gakhar, S.C (2003). Emotional Maturity of students at secondary stage” Journal of India Educational, Vol. 29 (3).

[10]. Goleman, D (1998). Emotional Intelligence. New York: Basic Books.

[11]. Judith, E., Cox, N. \& Darwin, B. (2008). Qualifying emotional intelligence; the relationship between thinking patterns and emotional skills. Journal of HumanisticCounseling, Education and Development. Vol. 47(2), pp. 9-12.

[12]. KakkarAlpana, (1999). Parental acceptance Rejection as related to problem of Adolescents: Indian Educational Abstract: NCERT, Vol. 1(1).

[13]. Kaur, S. (2000). A study of Emotional Maturity in relation to Environment factors. Unpublished Dissertation, Department of Education, Punjab University.

[14]. Larsen J.J. and Juhasz, A.M. (1985). The effects of knowledge of child development and social-emotional maturity on adolescent attitudes toward parenting. Retrieved from http://www.unboundmedicine.com/medline/citation/4083140/The_effects_of_knowledge_of_child_development_and_social_emoti onal on 25th May 2015.

[15]. Lau, S and Kwok, L.K. (2000). Relationship to family environment to adolescent, depression and self-concept. Social Behaviour and Personality: An International Journal, Vol. 28, pp. 41-50.

[16]. Mishra, A. N. (1994). Students and the hostel life-A study of university students, $\left(1^{\text {st }}\right.$ Ed), New Delhi, Mittal Publication, pp.1-226.

[17]. Nanda P., Chawla A. (2010). Impact of age and family type on emotional maturity of urban adolescent girls , http://www.aiaer.net/ejournal/vol19107/6.htm

[18]. Nelson, D., \& Low, G. (2005). Emotional Intelligence: Achieving academic and career excellence. Upper Saddle River, NJ: Prentice-Hall.

[19]. Rosa. M.C. and Preethi. C. (2012). Academic Stress and Emotional Maturity among Higher Secondary School Students of Working and Non-Working Mothers. International Journal of Basic and Advanced Research. Vol. 1(3), pp. 40-43. 